\title{
MOTHER'S KNOWLEDGE AND PRACTICE REGARDING PREVENTION AND MANAGEMENT OF DIARRHEA AMONG CHILDREN IN ODISHA, INDIA
}

\author{
Subas Chandra Behura \\ State Wash Consultant, UNICEF, Andhra Pradesh, India \\ P Kripalini, Sunita Jena \\ Regional Medical Research Center-ICMR Bhubaneswar, Odisha, India \\ Chandni Srivastava \\ State consultant RKSK, NHM, Raipur, Chhattisgarh, India \\ Henani Anand \\ State Coordinator- Odisha, IIHMR, Jaipur, Rajasthan, India \\ Bijaylaxmi Pradhan \\ Assistant Professor, Utkal University, Odisha, India
}

\begin{abstract}
Diarrhea is the second leading cause of death in children under five years old, and is responsible for killing around 760, 000 children every year, special in developing counters due to lack of Knowledge and practice in Diarrheal disease management. The main aim of this study was to assess mothers' knowledge and practice among mothers who have under five children, in two blocks of Rayagada, Odisha, India. A community based crosssectional study deign was conducted. The study was done from April- May 2014. To determine the sample size a single proportional formula was used. According to this formula the sample size of the study was 846. Multi-stage sampling technique was employed to select the study areas and study units. Among five kebeles, two kebeles were selected by simple random sampling techniques. Standardized interview questionnaires were adapted and modified from related articles and journals to collect data on the socio-demographic variables and factors associated with it. Pre-test was done in none sampling kebeles. Data were entered in Epi-info (version 3.5.1) statistical software package then exported to SPSS software package version 16.0 for further analysis. A total of 846 participants were included in the study. Of these, the response rate was 830(98.1\%). Five hundred twenty-eight 528(63.6\%) of them had good knowledge and 381(45.9\%) of them had good practice. The finding of this research indicated that
\end{abstract}

63.6\% of mothers had good knowledge towards Diarrhea management while $54.1 \%$ of mothers had poor practice on Diarrhea management.

Keywords - Diarrhea; Knowledge; Practice; Mother; under five Children; Management

\section{INTRODUCTION}

Diarrhea accounts for more than 3 million deaths annually (1). If we figure out the diarrheal death, then it is the fifth leading cause of mortality worldwide, specifically for the child mortality. The Government of India has launched the National Control of Diarrheal Diseases (CDD) program to reduce the mortality of infant from 95 to 50 and preschool mortality from 41.2 to 10 per 1000 by 2000 . As a part of Sixth Five Year Plan (1980-85) CDD program was implemented from 1980 with an objective of enhancing the knowledge and practices among the various health care providers to prevent the diarrhea related deaths. The CDD program was collaborated within Child Survival and Safe Motherhood (CSSM) program (2).

The growing urbanization in India is one of the vital public health challenges to cause diarrhea (3). As per the World Health report, $18 \%$ mortality of under- five children is due to diarrhea (4).Each year, rotavirus causes approximately 2 million hospitalizations cases, and 352,000-592,000 deaths 


\section{International Journal of Engineering Applied Sciences and Technology, 2019 Vol. 4, Issue 4, ISSN No. 2455-2143, Pages 94-99 \\ Published Online August 2019 in IJEAST (http://www.ijeast.com)}

(median, 440,000 deaths) in children under 5 years of age (5).Among the under 5 children, diarrhea is accountable for 1.5 billion incidents and 1.5-2.5 million deaths to occur annually (6-8). However, diarrhea related mortality among the under 5 has reduced in the past two decades and the reduction cause may be due to the proper case detection and management as per the Standard treatment guidelines which is recommended by WHO with the key management of using oral rehydration therapy (9).

Malnutrition accelerates the risk of diarrhea and its related mortality (10-12). Moderate to severe malnutrition accelerates the odds of diarrheal related mortality into 1.6 to 4.6 folds. Particularly the risk of diarrheal related death is higher among those who are suffering from vitamin A deficiency, Zinc deficiency (7). Study has shown that $13-21 \%$ (13). For the management of diarrhea, anti-diarrhea and antibacterial have minute role to play as per the WHO treatment guideline. However, mass education and community sensitization are the vital key for effective case detection and management, since it has the potential to build a contact between the health services and care providers to increase the ability of community to detect the danger signs of diarrhea among children and to encourage early care seeking behaviors (14). Health education can be provided if we can know the usual knowledge, attitude and practices (KAP) of the community. For that necessary and relevant information regarding the KAP of mothers about diarrhea is needed to prevent diarrheal related mortality as well as active case management (15).

Exclusive breast feeding protects many infants from many infections and diseases. Most of the infant between 3-6 months are prone to infections. Diarrhea was the most common infection, which can be shown in between 3-33 months (16). Studies have shown that the incidents of diarrhea among the uneducated mothers are high as compared to the mothers who have primary education. It was also found that in rural settings knowledge about ORS was less among the mothers (15 to 19 years) than the older mothers (17).

The awareness of mothers about health and health related illnesses is a key barometer for which we can get to know the progress of a family, community and a nation (18). Lack of knowledge and awareness in a thing can lead to improper utilization of the health services available in the community (19). Healthy practices of mother in a family can lead minimize the risk of morbidity of under five-year children. There is a vital correlation between the mother's knowledge and children's health since a child cannot take care of its own. Mother's knowledge regarding the cause, sign and symptoms, prevention and control is essential since she is the primary care provider for a child.

\section{OBJECTIVE OF THE STUDY}

The objective of the study was to assess and compare the knowledge level among mothers regarding the causes, prevention and management of diarrhoea.

\section{METHODOLOGY}

\section{Study design:}

Current study was a community based cross sectional descriptive study carried out in the district of Rayagada.

\section{Study setting:}

The study was conducted in the two blocks of Rayagada district which is a mineral-rich area in the southern part of the state Odisha, India. The District occupies a total area of $7,584.7 \mathrm{~km}$. Rayagada is divided into eleven blocks, from that 2 blocks were randomly selected.

\section{Data collection procedure:}

Data was collected from the participants using a standard questionnaire method as per case record format. The questionnaire schedule consisting of background information and questions to assess the knowledge and practice on the prevention and management of diarrhea among the mothers of under-five children. Questions prepared as per the IPHS (International Public Health Standards) and prepared format validated by the departmental developmental research committee. All the mothers who were qualified under the inclusion criteria along with informed consent are subjected to the KAP designed format for the record. The questionnaire consisted of 4 questions on knowledge and 4 on practice.

\section{Sample Size}

The sample size of the study was calculated based on the previous studies related to our topic. Based on the awareness and practices of previous studies, the sample size was calculated to be 400 with the use of "open epi tool". 400 mothers were approached for the study from them 392 agreed and met with the inclusion criteria.

\section{Study period}

This study was carried out from December 2018 to March 2018

\section{Inclusion, exclusion criteria and sources of data}

Mothers of under-five children residing in the study area and willing to participate in the study were included for this study.

\section{Statistical analysis}

All the data collected were entered into the Microsoft excel. The data analysis was carried out using SPSS software version 20. The level of knowledge and practice on management and prevention of diarrhea was calculated using mean, range, standard deviation, frequency and percentages.

\section{Ethical Consideration}

Ethical clearance was obtained from the Institutional Ethical committee of Asian Institute of Public Health (AIPH). Permission was taken from the concerned local authority. Consent was taken from the study participants and they were 
also informed that this study would not in any way harm them rather it will benefit the community. Data was only used for result interpretation and sharing. The results were shared first with the participants.

\section{RESULTS}

Out of 392 study participants majority of the mothers were from the two categories of age groups: 18-25 years $(67.85 \%)$ and 26-35 years $(25.76 \%)$ while in terms of occupation, almostall the mothers $(89 \%)$ were house wife and looking after house-related activities. Among the mothers most $(65 \%)$ were having secondary level of education followed by primary level education (18\%). Approximately half of the participants were from lower class of health index. More than $95 \%$ of the mothers were married and very few were divorced or widow. Mother who have 3-4 children were more (61\%) compared to1-2 children (36.7\%) and more than 5 children $(2.29 \%)$. Among the mothers $48.7 \%$ were Scheduled caste and more than $70 \%$ of them were Hindu.

\begin{tabular}{|l|l|l|}
\hline $\begin{array}{l}\text { Socio-demographic } \\
\text { factors }\end{array}$ & $\mathbf{n = 3 9 2}$ & Percentage (\%) \\
\hline Age & \multicolumn{2}{l|}{} \\
\hline Below18 & 8 & 2.04 \\
\hline $18-25$ & 266 & 67.85 \\
\hline $26-35$ & 101 & 25.76 \\
\hline 35 above & 17 & 4.33 \\
\hline Education & \multicolumn{2}{|l|}{} \\
\hline No formal education & 39 & 9.94 \\
\hline Primary & 71 & 18.11 \\
\hline Secondary & 256 & 65.30 \\
\hline Graduate \& above & 26 & 6.63 \\
\hline Occupation & \multicolumn{2}{|l|}{} \\
\hline Private service & 13 & 3.31 \\
\hline Daily labor & 19 & 4.84 \\
\hline House wife & 349 & 89.03 \\
\hline Student & 11 & 2.80 \\
\hline Health Index & \multicolumn{2}{|l}{} \\
\hline Upper class & 21 & 5.35 \\
\hline Middle class & 164 & 41.83 \\
\hline Lower class & 207 & 52.80 \\
\hline Marital Status & 373 & 95.15 \\
\hline Married & 13 & 3.31 \\
\hline Divorced/Separated & 6 & 60.96 \\
\hline Widow & \multicolumn{2}{|l|}{} \\
\hline Numbers of Children & \multicolumn{2}{|l|}{} \\
\hline 1-2 & \multicolumn{2}{|l|}{} \\
\hline 3-4 & \multicolumn{2}{|l|}{} \\
\hline
\end{tabular}

\begin{tabular}{|l|l|l|}
\hline$>5$ & 9 & 2.29 \\
\hline Caste & 99 & 25.25 \\
\hline General & 191 & 48.72 \\
\hline SC & 57 & 14.54 \\
\hline ST & 45 & 11.47 \\
\hline OBC & \multicolumn{2}{|l|}{} \\
\hline Religion & 282 & 71.93 \\
\hline Hindu & 88 & 22.44 \\
\hline Muslim & 19 & 4.84 \\
\hline Christian & 3 & 1.53 \\
\hline Others
\end{tabular}

Table 1: Mother's Socio-demographic Characteristics n=392

\begin{tabular}{|c|c|c|}
\hline Variables & $\mathbf{n}$ & $(\%)$ \\
\hline \multicolumn{3}{|c|}{$\begin{array}{l}\text { Mothers' Knowledge about Source of Diarrheal } \\
\text { Disease }\end{array}$} \\
\hline Health Professionals & 223 & 56.88 \\
\hline News Paper & 7 & 1.78 \\
\hline Television and Radio & 87 & 22.19 \\
\hline Friends & 32 & 8.16 \\
\hline Have no Knowledge & 43 & 10.96 \\
\hline \multicolumn{3}{|c|}{ Knowledge of Mother on the Cause of Diarrhoea } \\
\hline Poor Hygiene & 227 & 57.90 \\
\hline Bacteria & 119 & 30.35 \\
\hline Virus & 5 & 1.27 \\
\hline Intestinal Parasite & 4 & 1.02 \\
\hline Have no Knowledge & 37 & 9.43 \\
\hline \multicolumn{3}{|c|}{$\begin{array}{l}\text { Knowledge of Mothers' on Impact of Diarrhoea } \\
\text { Disease on Under Five Children }\end{array}$} \\
\hline $\begin{array}{l}\text { Mortality and } \\
\text { morbidity }\end{array}$ & 282 & 71.93 \\
\hline $\begin{array}{l}\text { Growth and } \\
\text { retardation }\end{array}$ & 79 & 20.15 \\
\hline Have no knowledge & 31 & 7.90 \\
\hline \multicolumn{3}{|c|}{$\begin{array}{l}\text { Knowledge of Mother on Home Fluid Management of } \\
\text { Diarrheal Diseases }\end{array}$} \\
\hline Only Water & 89 & 22.70 \\
\hline $\begin{array}{l}\text { Water with Salt \& } \\
\text { Sugar }\end{array}$ & 246 & 62.75 \\
\hline Soup & 18 & 4.59 \\
\hline Juice & 39 & 9.94 \\
\hline
\end{tabular}

Table 2: Knowledge of Mothers on Diarrheal Disease

Table no 2 shows the knowledge of mothers on diarrheal disease. The mothers said health professional (56.9\%) and Television and Radio (22.19\%) were the main sources of information. Majority (58\%) of mothers had knowledge about poor hygiene is cause of diarrhea, followed by bacteria $(30.3 \%)$ Most of the mothers consider that growth retardation $(80 \%)$ is important impact of diarrhea and few (28\%) consider mortality and morbidity, whereas $31 \%$ did not have any idea about impact of diarrheal disease. More than half (63\%) of the 


\section{International Journal of Engineering Applied Sciences and Technology, 2019 \\ Vol. 4, Issue 4, ISSN No. 2455-2143, Pages 94-99 \\ Published Online August 2019 in IJEAST (http://www.ijeast.com)}

mothers had knowledge regarding the home fluid management, as Water with Salt \& Sugar (93.7\%), Only Water $(22.7 \%)$, Juice $(9.94 \%)$ and soup $(04.59 \%)$ should be feeded at the time of diarrhea.

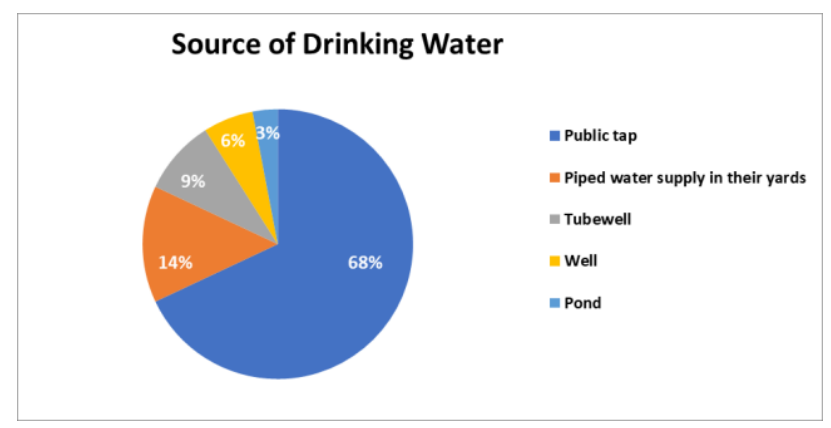

Fig 1: Source of drinking water

Figure 1 describe that more than half of mother ware taking drinking water from $(68 \%)$ public tap followed by piped water in their yard (14\%), tube-well $(9 \%)$, well $(6 \%)$ and pound $(3 \%)$.

\begin{tabular}{|l|l|l|}
\hline \multicolumn{1}{|c|}{ Variables } & Yes (n, \%) & No (n, \%) \\
\hline $\begin{array}{l}\text { Did mothers take any } \\
\text { measure to manage } \\
\text { diarrhoea? }\end{array}$ & $241(61.4 \%)$ & $151(38.7 \%)$ \\
\hline $\begin{array}{l}\text { Did mothers prepare any } \\
\text { fluid to manage diarrhoea at } \\
\text { home? }\end{array}$ & $209(53.3 \%)$ & $183(46.68 \%)$ \\
\hline $\begin{array}{l}\text { Have mothers ever given } \\
\text { home prepared fluid at } \\
\text { home? }\end{array}$ & $211(53.82 \%)$ & $181(46.1 \%)$ \\
\hline $\begin{array}{l}\text { Did you give zinc therapy } \\
\text { to your child during } \\
\text { diarrhoea? }\end{array}$ & $119(30.3 \%)$ & $273(69.6 \%)$ \\
\hline
\end{tabular}

Table 3: Mothers' practice on diarrheal disease management

Table 3 present the practice of mothers to manage diarrhea. More than half of mother took measure to manage diarrhea $(61.4 \%)$, prepared any fluid to manage diarrhea at home $(53.3 \%)$, have ever given home prepared fluid (53.82\%) and have given zinc therapy to their child during diarrhea $(30.3 \%)$.

\section{DISCUSSION}

The current study "Mother's knowledge and practice regarding prevention and management of diarrhea among children" is based on the analysis of total 392 mothers of children. The study shows majority of the mothers were 18-25 years of age group i.e. $266(67.85 \%), 101(25.76 \%)$ were of 26-35 years of age group, $17(4.33 \%)$ were 35 years and above and only $8(2.04 \%)$ were below 18 years of age group. In this study, social determinants stated that 256 (65. 30\%) mothers were having secondary education, $71(18.11 \%)$ were having primary education, $26(6.63 \%)$ were having graduation and above and only $39(9.94 \%)$ were illiterate. In socioeconomic status category, $21(5.35 \%)$ belonged to upper class, 164 (41.83\%) belonged to middle class and $207(52.80 \%)$ belonged to lower class.

In this study, good knowledge about diarrhea was seen in 349 $(89.01 \%)$ of mothers and among them $223(56.88 \%)$ got the information from health professionals. About 87 (22.19\%) got the information from television and radio. About the cause of diarrhea $227(57.90 \%)$ mothers answered the cause of diarrhea is poor hygiene. Also, about $119(30.35 \%)$ mothers told the cause of diarrhea is bacteria. Study found 37 (9.43\%) mothers did not have knowledge on the cause of diarrhea. This is in line with studies conducted in Iran $64.3 \%$ and Pakistan $75 \%$ (20).

$282(71.93 \%)$ mothers had knowledge on impact of diarrhea is mortality and morbidity. About $79(20.15 \%)$ mothers told the impact of diarrhea causes growth and retardation. 31 (7.90\%) mothers had no knowledge about the impact of diarrhea. This result, are consistent with the study by Hackett KM et al showing $47 \%$ of the mothers did not know the causes of diarrhea (21). In a study by NeelmaKunwar et al showed that $72 \%$ of the mothers knew the correct definition of diarrhea which is higher than this study result (2). The study done by Saha et al. indicated that $<20 \%$ of mothers were aware of preventive measures of Diarrheal disease; like nutrition, medication, breastfeeding, proper disposal of human waste, and vaccines (22).

Regarding practice assessment of mother in this study, we found that, similar the studies conducted in Nepal (23) and Hilly region of Uttarakhand $16.5 \%$ knew the correct method of sugar salt solution preparation (24). This might be due to its use being uncommon and mothers might not have any prior exposure to it. Furthermore, its ingredients were not available in ready-made form unlike an ORS sachet and thus there may be more chances of errors during its preparation. Our study also found more than $50 \%$ of mothers were drinking water from public tap $(68 \%)$, yard $(14 \%)$, tube well $(9 \%)$, well $(6 \%)$ and pound (3\%).

This study revealed that illiterate mothers had poor knowledge towards Diarrhea management as compared to educated mothers. The fact is that as the educational level of the mothers increased the level of awareness and knowledge becomes increase. With the scope of this study, there is no empirical evidence available to confirm why this happened.

\section{CONCLUSION}

In order to prevent diarrhea, health education plays a vital role for effective case management in a community. Community health education established a relationship between the care provider and the community health worker. The awareness of mothers about the disease prevention and health promotion is 


\section{International Journal of Engineering Applied Sciences and Technology, 2019 \\ Vol. 4, Issue 4, ISSN No. 2455-2143, Pages 94-99 \\ Published Online August 2019 in IJEAST (http://www.ijeast.com)}

the key asset which can progress the health status of a family, hence a community and ultimately our nation. Mothers are the primary care provider in a family and her knowledge and healthy practices are very essential for decreasing morbidity and mortality due to diarrhea. Thus, there is a need for extensive educational interventions in a community especially to the mothers for the improvement in their knowledge and practices about childhood diarrhea and its early management at home.

\section{RECOMMENDATION}

To prevent diarrheal related deaths, at the earliest stage its detection of danger signs at home is essential to treat and manage dehydration and diarrhea. Preventive efforts should be taken to control diarrheal diseases by increasing the level of knowledge and practice of the primary care giver/ mothers. Community health workers should perform surveillance activities for early detection of problem and health education should be given and implemented in order to increase the knowledge and behavioral practices among mothers in a community.

\section{REFERENCE}

1. Chaudhary, P., Basu, S., Dzeyie, A.K., Gulla, S., Khade, S., Patel, A., Phukan, D., Dikid, T., Kumar, A. and Shrivastava, A., 2014. Knowledge, Attitude and Practice of Mothers regarding Diarrhoeal Illness in Children under Five Years of Age: A Cross Sectional Study in an Urban Slum of Delhi, India. The J Communicable Diseases, 46(3), pp.13-21.

2. Padhy, S., Sethi, R.K. and Behera, N., 2017. Mother's knowledge, attitude and practice regarding prevention and management of diarrhoea in children in Southern Odisha. Int $\mathbf{J}$ Contemp Pediatr, 4(3), pp.966-71.

3. Sethi, L., 2016. Effectiveness of planned health teaching on knowledge and practices regarding prevention and management of diarrhea among the mothers of under-five age group children in a selected slum of Indore city. Nursing and Midwifery Research, 12(1), p.25.

4. Pahwa, S., Kumar, G.T. and Toteja, G.S., 2010. Performance of a community-based health and nutritioneducation intervention in the management of diarrhoea in a slum of Delhi, India. Journal of health, population, and nutrition, 28(6), p.553.

5. Parashar, U.D., Hummelman, E.G., Bresee, J.S., Miller, M.A. and Glass, R.I., 2003. Global illness and deaths caused by rotavirus disease in children. Emerging infectious diseases, 9(5), p.565.

6. Chiabi, A., Nguefack, F.D., Nguefack, S., Njedock, N.S., Abouame, P.H., Chiabi, E.N., Chiabi, R.M. and Obama, M.T., 2018. Assessment of Knowledge and Practices of Mothers on the Home Management of Diarrhea in the Northern Part of Cameroon. Progressing Aspects in Pediatrics and Neonatology, 1(3), pp.42-46.
7. Lamberti, L.M., Walker, C.L.F., Taneja, S., Mazumder, S. and Black, R.E., 2015. The association between provider practice and knowledge of ORS and zinc supplementation for the treatment of childhood diarrhea in Bihar, Gujarat and Uttar Pradesh, India: a multi-site cross-sectional study. PloS one, 10(6), p.e0130845.

8. Mumtaz, Y., Zafar, M. and Mumtaz, Z., 2014. Knowledge attitude and practices of mothers about diarrhea in children under 5 years. J Dow Uni Health Sci, 8(1), pp.3-6.

9. Berisha, M., Hoxha-Gashi, S., Gashi, M. and Ramadani, N., 2009. Maternal Practice on Management of Acute Diarrhea among Children Under Five Years Old in Kosova. TAF Preventive Medicine Bulletin, 8(5).

10. Saberi, F., Amini, S. and Jan Nesari, R., 2014. Mothers' roles in prevention and care of diarrhea in children of aran and bidgol, iran. Nurs Midwifery Stud, 3(2), p.e19985.

11. Amare, D., Dereje, B., Kassie, B., Tessema, M., Mullu, G., Alene, B. and Ayele, A., 2014. Maternal knowledge and practice towards diarrhoea management in under five children in fenote selam town, west gojjam zone, amhara regional state, Northwest Ethiopia, 2014. Journal of Infectious Diseases and Therapy.

12. Abdinia, B., 2014. Knowledge and practice of mothers in the management of children's Diarrhea, in Northwest, Iran. Archives of Pediatric Infectious Diseases, 2(4).

13. Rehan, H.S., Gautam, K. and Gurung, K., 2003. Mothers needs to know more regarding management of childhood acute diarrhea. Indian J PrevSoc Med, 34(1), pp.40-5.

14. Merali, H.S., Morgan, M.S. and Boonshuyar, C., 2018. Diarrheal knowledge and preventative behaviors among the caregivers of children under 5 years of age on the Tonle Sap Lake, Cambodia. Research and reports in tropical medicine, 9, p.35.

15. Muthulakshmi, M. and Gopalakrishnan, S., 2017. Use of oral rehydration solution by mothers of under-five children in a rural area of Kancheepuram district, Tamil Nadu: a KAP study. International Journal Of Community Medicine And Public Health, 4(11), pp.4326-4332.

16. Ramachandran, P. and Gopalan, H.S., 2011. Assessment of nutritional status in Indian preschool children using WHO 2006 Growth Standards. The Indian journal of medical research, 134(1), p.47.

17. Ghatam, A., Maktha, V.K., Katiki, S.V. and Koka, B., 2017. Knowledge regarding oral rehydration solution among mothers of under five children from a rural area of Rangareddy district, Telangana. International Journal Of Community Medicine And Public Health, 3(6), pp.1487-1490. 18. Kier, P.P.D. and Dai, Y.C., 2018. Mothers' knowledge, attitudes and practices on preventing diarrhoea in Juba, South Sudan. South Sudan Medical Journal, 11(3), pp.60-64.

19. Ansari, M., Ibrahim, M.I.M. and Shankar, P.R., 2012. Mothers' Knowledge, Attitude and Practice Regarding Diarrhea and its Management in Morang Nepal: An Interventional Study. Tropical Journal of Pharmaceutical Research, 11(5), pp.847-854. 
20. Khalili, M., Mirshahi, M., Zarghami, A., Rajabnia, M. and Farahmand, F., 2013. Maternal knowledge and practice regarding childhood diarrhea and diet in Zahedan, Iran. Health scope, 2(1), pp.19-24.

21. Hackett, K.M., Mukta, U.S., Jalal, C.S. and Sellen, D.W., 2015. A qualitative study exploring perceived barriers to infant feeding and caregiving among adolescent girls and young women in rural Bangladesh. BMC public health, 15(1), p.771.

22. Desta, B.K., Assimamaw, N.T. and Ashenafi, T.D., 2017. Knowledge, practice, and associated factors of home-based Management of Diarrhea among caregivers of children attending under-five Clinic in Fagita Lekoma District, Awi zone, Amhara regional state, Northwest Ethiopia, 2016. Nursing research and practice, 2017.

23. Ansari, M., Ibrahim, M.I.M. and Shankar, P.R., 2012. Mothers' Knowledge, Attitude and Practice Regarding Diarrhea and its Management in Morang Nepal: An Interventional Study. Tropical Journal of Pharmaceutical Research, 11(5), pp.847-854.

24. Singh, A.K., Dixit, S., Gupta, S. and Bhatt, N., 2012. Knowledge, attitute and practices of mothers regarding acute diarrhea management in the urban population of hilly region of uttarakhand. Journal of Evolution of Medical and Dental Sciences, 1(1), pp.2-8. 